\title{
Unexpected dietary preferences of Eurasian Spoonbills in the Dutch Wadden Sea: spoonbills mainly feed on small fish not shrimp
}

\author{
Jeltje Jouta ${ }^{1,2}\left(\right.$ Detra de Goeij ${ }^{1,2,3} \cdot$ Tamar Lok $^{2,4} \cdot$ Estefania Velilla $^{2,5} \cdot$ Cornelis J. Camphuysen ${ }^{2} \cdot$ Mardik Leopold $^{6}$. \\ Henk W. van der Veer ${ }^{2} \cdot$ Han Olff ${ }^{1} \cdot$ Otto Overdijk $^{3} \cdot$ Theunis Piersma $^{1,2}$
}

Received: 20 December 2017 / Revised: 26 February 2018 / Accepted: 7 March 2018 / Published online: 24 March 2018

(c) The Author(s) 2018

\begin{abstract}
After an historical absence, over the last decades Eurasian Spoonbills Platalea leucorodia leucorodia have returned to breed on the barrier islands of the Wadden Sea. The area offers an abundance of predator-free nesting habitat, low degrees of disturbance, and an extensive intertidal feeding area with increasing stocks of brown shrimp Crangon crangon, the assumed main prey of $P$. leucorodia leucorodia. Nevertheless, newly established and expanding colonies of spoonbills have surprisingly quickly reached plateau levels. Here we tested the often stated assertion that spoonbills mainly rely on brown shrimp as food, by quantifying the diet of chicks on the basis of regurgitates and by analysis of blood isotopes using stable isotope Bayesian mixing models. Both methods showed that, rather than brown shrimp being the staple food of spoonbill chicks, small flatfish (especially plaice Pleuronectes platessa) and gobies (Pomatoschistus spp.) were their main prey. Unlike shrimp, small flatfish have been reported to be rather scarce in the Wadden Sea in recent years, which may explain the rapid saturation of colony size due to food-related density-dependent recruitment declines of growing colonies. By way of their diet and colony growth characteristics, spoonbills may thus indicate the availability of small fish in the Wadden Sea. We predict that the recovery to former densities of young flatfish and other juvenile/small fish in the Wadden Sea will be tracked by changing diets (more fish) and an increase in the size of Eurasian Spoonbill colonies across the Wadden Sea.
\end{abstract}

Keywords Platalea leucorodia leucorodia $\cdot$ Regurgitate analysis · Restoration · Stable isotope analysis in R · Intertidal · Bayesian mixing models

\section{Zusammenfassung}

Unerwartete Nahrungsvorlieben bei Löfflern Platalea leucorodia leucorodia im niederländischen Wattenmeer: Statt Garnelen fressen Löffler hauptsächlich kleine Fische

Nach längerer Abwesenheit in der Vergangenheit ist der Löffler Platalea leucorodia leucorodia während der letzten Jahrzehnte als Brutvogel auf die vorgelagerten Inseln des Wattenmeeres zurückgekehrt. Dieser Lebensraum bietet reichlich prädatorfreies Nisthabitat, ein geringes $\mathrm{Ma}$ an Störungen sowie räumlich scheinbar grenzenlose Nahrungsflächen in der Gezeitenzone mit zunehmenden Beständen an Nordseegarnelen Crangon crangon, welche als die Hauptbeute der Löffler gelten. Dennoch haben die neugegründeten und sich ausdehnenden Kolonien überraschend schnell ihre Sättigungsgrenze erreicht. Hier überprüften wir die oft geäußerte Behauptung, dass Löffler hauptsächlich auf Nordseegarnelen als Nahrung angewiesen sind, indem wir die Kükennahrung anhand von Speiballen und durch Analysen der Isotope im Blut mittels Bayes'scher gemischter Modelle stabiler Isotope quantifizierten. Bei beiden Methoden zeigte sich, dass nicht, wie erwartet, vorwiegend Nordseegarnelen an die Löfflerküken verfüttert wurden, sondern dass kleine Plattfische (besonders Scholle Pleuronectes platessa) und Grundeln (Pomatoschistus spp.) die Hauptbeute darstellten. Anders als die Garnelen sind kleine Plattfische im Wattenmeer in den letzten Jahren selten geworden, was aufgrund nahrungsbedingter und dichteabhängiger Abnahmen der Rekrutierungsraten wachsender Kolonien das schnelle Erreichen der Sättigungsgrenze bezüglich der Koloniegröße erklären könnte. Aufgrund ihrer Ernährungsweise und ihrer Koloniewachstumseigenschaften könnten Löffler so die

Communicated by C. Barbraud.

Extended author information available on the last page of the article 
Verfügbarkeit kleiner Fische im Wattenmeer anzeigen. Wir sagen voraus, dass eine Bestandserholung junger Plattfische und anderer juveniler beziehungsweise kleiner Fische zu früheren Dichten im Wattenmeer an einer veränderten Nahrungszusammensetzung (mehr Fische) und einer wachsenden Koloniegröße der Löffler im gesamten Wattenmeer erkennbar sein wird.

\section{Introduction}

The Wadden Sea, the area of shallows and intertidal flats between the northwestern coast of the European mainland and the barrier islands which create a border to the North Sea, provides a vast habitat for marine and estuarine species, including those that connect the Wadden Sea with ecosystems elsewhere on the globe, i.e. migratory shorebirds (Swennen 1976; van de Kam et al. 2004; Reise et al. 2010; van Roomen et al. 2012). This ecosystem is subject to many external forces, many of the human ones contributing to the degradation of ecosystem functioning (de Jonge and Essink 1993; Wolff 2005; Eriksson et al. 2010). In recent decades, following recognition of the Wadden Sea's importance, such as its RAMSAR status and, more recently, its designation as a UNESCO World Heritage Site, attempts have been made to conserve and restore the biodiversity and ecosystem functioning of this sea (Boere and Piersma 2012).

The return of the Eurasian Spoonbill Platalea leucorodia leucorodia as a breeding bird to the Wadden Sea barrier islands, after an historical absence of many centuries due to human persecution (de Goeij et al. 2015), counts as a tangible result of successful conservation measures. From the late 1960s onwards, the number of spoonbill breeding pairs increased exponentially in the Dutch Wadden Sea (de Goeij et al. 1985; Lok et al. 2009; Oudman et al. 2017), as a result of favourable circumstances on the Wadden Sea islands due to the enforced protection of foraging and breeding areas (de Goeij et al. 1985; Kemper 1986a; van der Hut 1992). This increase in numbers has been partly due to resettlement from mainland colonies threatened by red fox predation, from immigration due to other factors, and also a result of local recruitment (Lok et al. 2009). Indeed, the Wadden Sea seems to provide everything that reproductively active spoonbills need: plenty of suitable nesting places with little or no predation, very low degrees of disturbance, and extensive foraging areas in the form of shallow gullies and tidal flats.

It has therefore been surprising that newly established and expanding colonies in the Wadden Sea have quickly reached plateau levels (Lok et al. 2009; Oudman et al. 2017), the increase of the total breeding numbers being driven to a large extent by the formation of new colonies near previously unoccupied areas of intertidal flats. Growing colonies show signs of density dependence as (1) the number of fledglings per nest has declined with colony size (Lok et al. 2009; Oudman et al. 2017), and (2) the post-fledging survival rates of spoonbills have declined with an increase of overall population size (Lok et al. 2013). In view of the large unused areas of what appears to be high-quality breeding habitat, it has been suggested that food might be the factor causing density dependence and limiting population size in the Eurasian Spoonbill (Oudman et al. 2017).

Shrimp Crangon crangon have been repeatedly reported as being the main prey of spoonbills, especially during the chick-rearing period (Tinbergen 1933; Kemper 1986a, b; Wintermans and Wymenga 1996; Altenburg and Wymenga, 1997; Fig. 1). However, de Goeij et al. (1985) indicated that a high availability of young plaice in pools in the Wadden Sea during low tide would provide easy prey for spoonbills. The fact that the food of spoonbills might be limiting, and that several colonies reached plateau levels more than 10 years ago (e.g. on the islands of Terschelling and Schiermonnikoog), can possibly be explained either by (1) shrimp becoming more abundant (Tulp et al. 2012), but shrimp not actually being the staple food of these birds; or (2) by shrimp availability actually being lower than thought, e.g. as a result of high fishing pressure, as reported by Tulp et al. (2016). In this study we aim to examine these possibilities by studying the diet of nestling spoonbills across the colonies of the Dutch Wadden Sea, using both regurgitates and isotopic Bayesian mixing models (stable isotope analysis in $\mathrm{R}$; SIAR) based on stable carbon $\left(\delta^{13} \mathrm{C}\right)$ and nitrogen $\left(\delta^{15} \mathrm{~N}\right)$ isotopes in bird blood and prey tissue samples to estimate the diet of chicks. SIAR was used to model the isotopic (food web) position of spoonbills relative to their prey by using $\delta^{13} \mathrm{C}$ and $\delta^{15} \mathrm{~N} ; \delta^{13} \mathrm{C}$ is useful for discrimination between marine and terrestrial organisms, while $\delta^{15} \mathrm{~N}$ is useful when studying trophic position (Hobson and Welch 1992; Polis and Hurd 1995; Post 2002). By identifying the staple foods of spoonbills, we can suggest the best conservation management practices for them in the Wadden Sea.

\section{Materials and methods}

Spoonbills are tactile foragers and have altricial chicks that are fed by the parents (Hancock et al. 2010). After a breeding period of about 25 days, during which both parents incubate the eggs, most chicks hatch from early to mid-May (Lok et al. 2017). During the breeding season spoonbills are bound to the nest and therefore restricted to a foraging range of less than 30-40 km from the breeding colony (Altenburg and Wymenga 1997). Although this foraging range allows them to forage in both marine and freshwater resources, 
Fig. 1 A spoonbill chick producing a regurgitate upon being held after capture. At first sight such regurgitates only show the remains of shrimp

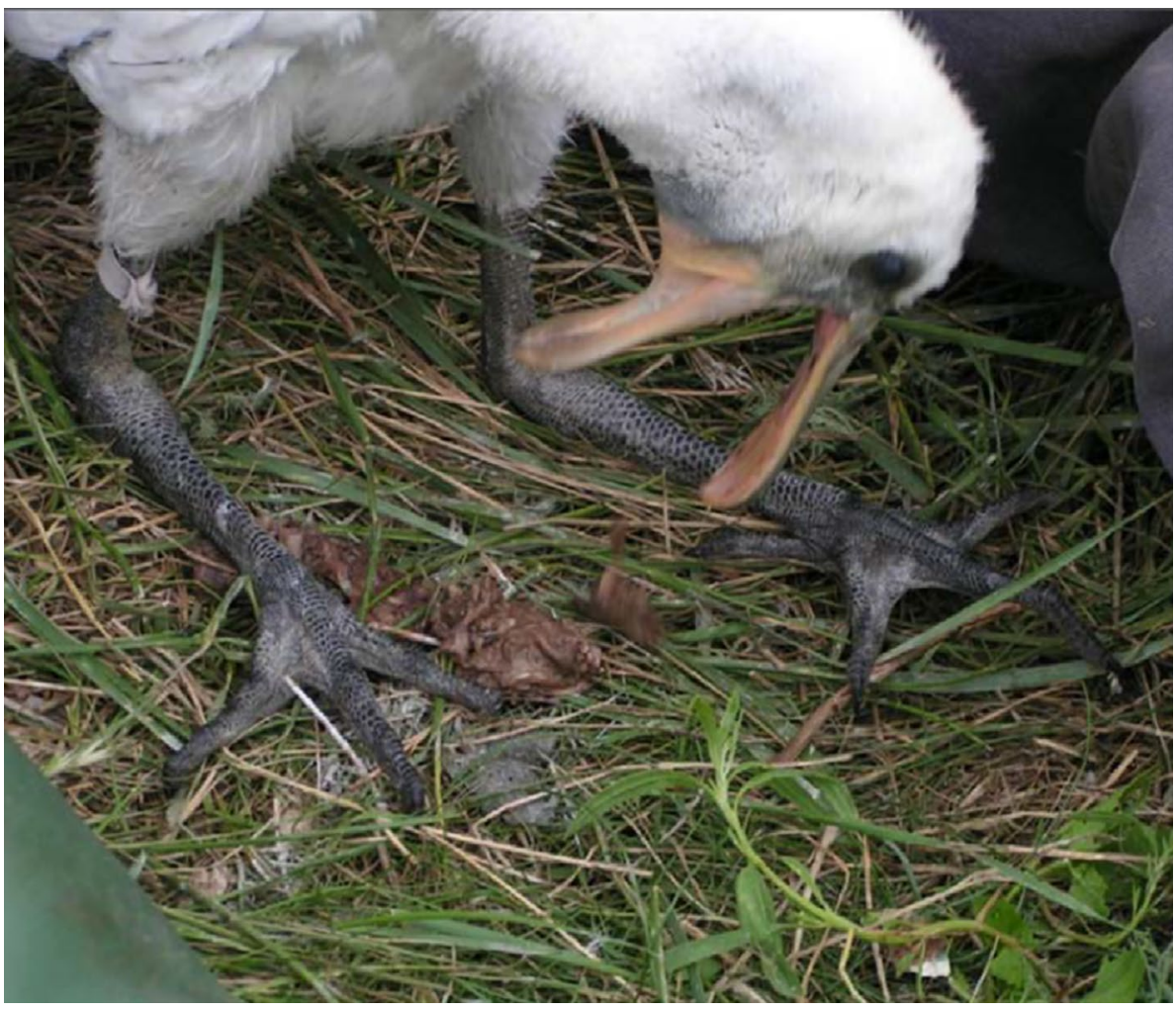

chicks appear mainly to be fed with marine prey likely captured in the Wadden Sea (El-Hacen et al. 2014).

The diet of spoonbill chicks in colonies on the barrier islands of the Wadden Sea was assessed from regurgitates and from blood stable isotope analyses. Whereas regurgitates reflect the diet on the day of collection, stable isotope analyses indicate the diet integrated over longer periods: a few days if based on blood plasma, a few weeks if based on red blood cells (RBC) (e.g. Dietz et al. 2010; Hahn et al. 2012). Both methods are ideal for diet reconstruction, with the caveat that small prey and easily digestible prey may be missed when using diet reconstruction based on regurgitates, while the isotopic mixing model SIAR is an indirect method and requires precise assumptions (e.g. about discrimination factors and selection of potential prey for SIAR).

From 17 May to 12 July 2012 and 12 June-7 August 2013, a total of 301 chicks aged 15-35 days were examined in colonies on five islands in the Dutch Wadden Sea (Fig. 2). Within $1 \mathrm{~h}$ after capture the birds were colour-ringed, body size measures were taken (see Lok et al. 2014) and a blood sample of 150-400 $\mu \mathrm{l}$ was taken from the brachial vein in heparinized capillaries. Within $3 \mathrm{~h}$ after sampling, blood plasma and RBC were separated in Eppendorf cups in a haematocrit centrifuge (Sigma 1-13 microfuge; 6 min at 5000 r.p.m.). Plasma and RBC were pipetted into separate glass vials. Samples were transported in a bag with cooling elements for maximally $4 \mathrm{~h}$ before storage at $-20{ }^{\circ} \mathrm{C}$ until analysis. To obtain the isotope values of potential prey, 209 food items were collected from 12 April to 17 May 2012 and 2 May-12 July 2013 in all potential feeding habitats of spoonbills. Prey collection occurred at locations where spoonbills were foraging at that moment or were known to forage frequently. The proportions of prey species as calculated by regurgitate analyses was used as a prior for prey selected in the stable isotopic based diet reconstruction SIAR (all prey species that compromised $>2 \%$ of the total diet). In order to limit the number of prey input into SIAR, we combined all important prey species in freshwater and mixture sources, while using all important prey of the marine water source. Prey categorized under 'mixture' are prey that occur in marine, brackish and freshwater habitat types. An overview of the prey species used for diet reconstruction with the help of isotopic mixing models (SIAR) is given in Table 1. C isotopes of prey were normalized a posteriori for the effect of lipid concentration, using a correction based on the C:N ratio given by Post et al. (2007) (Table 1).

Stable isotope values of spoonbill chicks are shown in Table 2. As explained by Cherel et al. (2005), lipid extraction of plasma is required to measure adequate $\delta^{13} \mathrm{C}$ plasma values, especially since the $\mathrm{C}: \mathrm{N}_{\text {plasma }}$ ratios of spoonbill chicks in this study are high (>4.0). Although lipid correction is needed, we were not able to repeat the analyses with lipid-extracted samples. We did not find an a posteriori lipid correction model to 'normalize' bird plasma for the lipid contribution.

To reconstruct diet composition with stable isotopes, we measured the $\mathrm{C}$ and $\mathrm{N}\left(\delta^{13} \mathrm{C}\right.$ and $\left.\delta^{15} \mathrm{~N}\right)$ of blood plasma 
Fig. 2 Map with overview of the Eurasian Spoonbill colonies on the five Dutch Wadden Sea islands where spoonbill samples were collected

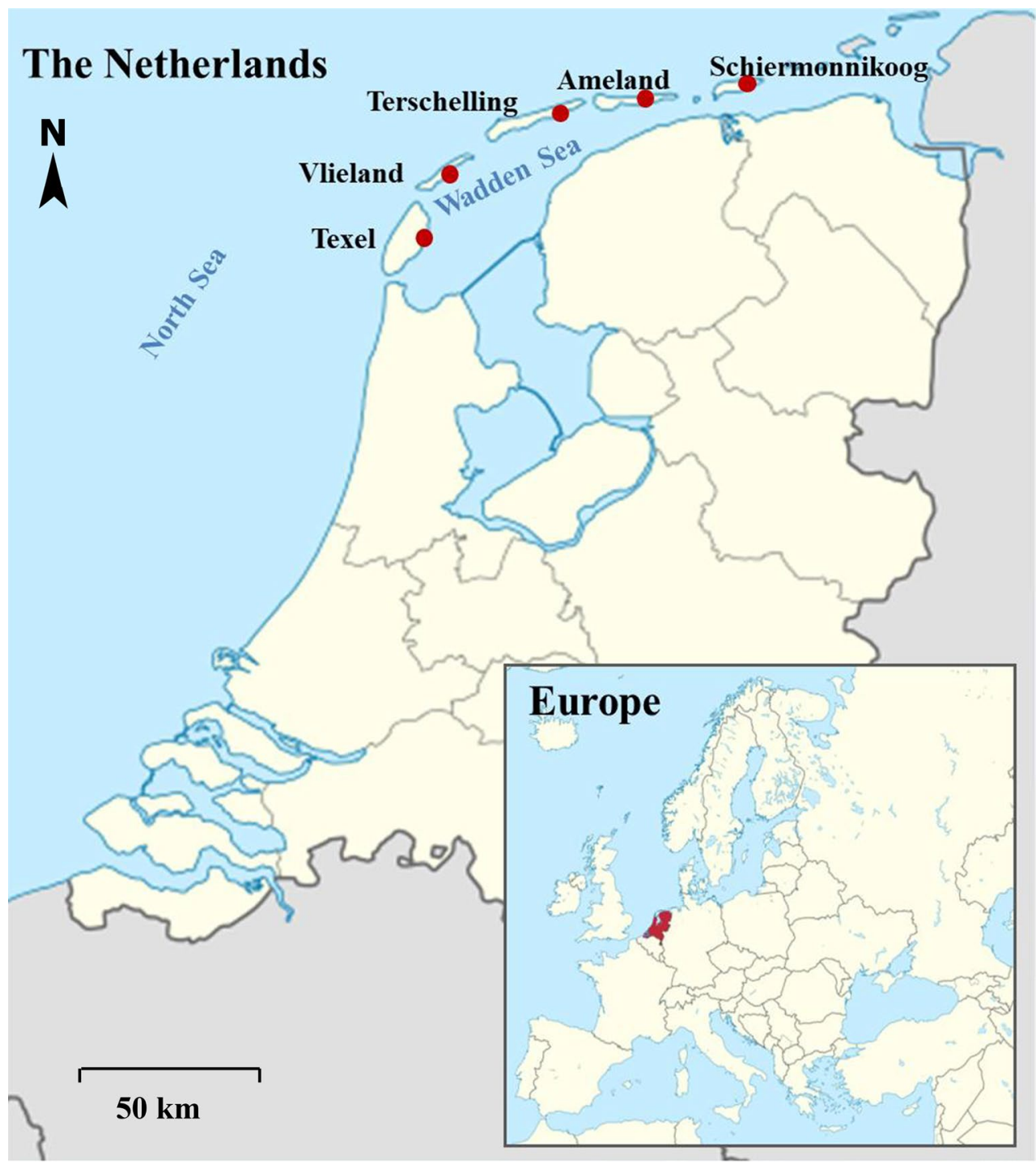

and $\mathrm{RBC}$ of spoonbill nestlings and of the relevant muscle tissue of prey species. All samples were freeze-dried before grinding them with a pestle and mortar. Next, $0.4-0.8 \mathrm{mg}$ of sample material was weighed on a microbalance (Sartorius CP2P) and put into $5 \times 8$-mm tin capsules. The $\delta^{13} \mathrm{C}$ and $\delta^{15} \mathrm{~N}$ isotope values were determined by a Thermo Flash 2000 elemental analyser coupled to a Thermo Delta $\mathrm{V}$ isotope ratio mass spectrometer. Isotope values were calibrated to a laboratory acetanilide standard $\left(\delta^{13} \mathrm{C} 26.1 \%\right.$ and $\delta^{15} \mathrm{~N} 1.3 \%$ calibrated to NBS-22 and IAEA-N1, respectively) and corrected for the blank. The results are reported on a per mill scale with respect to Vienna Pee Dee belemnite for $\delta^{13} \mathrm{C}$ and to atmospheric $\mathrm{N}_{2}$ for $\delta^{15} \mathrm{~N}$. The replicate error of the standard, acetalinide, ranged between 0.01 and 0.05 , when using one standard every 2.2-6.3 samples. The mean diets of all birds were calculated per island for the 2 years combined.
The relative contribution of potential prey species to the diet of spoonbill chicks was estimated using an isotopic Bayesian mixing model programmed in the R-package SIAR version 4.2 (Parnell et al. 2010). The SIAR model requires input of at least two stable isotopes (here $\delta^{15} \mathrm{~N}$ and $\delta^{13} \mathrm{C}$ ) of a consumer, its prey, and a diet-tissue differentiation factor. As prey sources we used all prey species that occurred at $>2 \%$ in the spoonbill diet assessed by regurgitate analysis (Table 1 ). In order to keep the number of food sources for SIAR low (Phillips et al. 2014), prey that occurred in freshwater or in multiple water types were grouped, since (late-breeding) spoonbills mainly forage on marine Wadden Sea sources (El-Hacen et al. 2014). We did not measure differentiation factors ourselves so we used general ones for avian plasma $\left(\delta^{15} \mathrm{~N}, 2.82 \pm 0.14 \% ; \delta^{13} \mathrm{C}\right.$, $-0.08 \pm 0.38 \%$ ) and avian RBC $\left(\delta^{15} \mathrm{~N}, 2.25 \pm 0.20 \%\right.$; $\delta^{13} \mathrm{C},-0.35 \pm 0 \%$ ) as presented by Caut et al. (2009). 
Table 1 Mean stable isotope values of nitrogen $\left(\delta^{15} N\right)$ and carbon $\left(\delta^{13} C\right)$ of prey used as input for diet reconstruction in the stable isotope mixing model (stable isotope analysis in R; SIAR)

\begin{tabular}{|c|c|c|c|c|c|c|c|c|c|c|c|}
\hline \multirow[t]{2}{*}{ Water type } & \multirow[t]{2}{*}{ Island } & \multirow[t]{2}{*}{ Species } & \multicolumn{2}{|l|}{$\delta^{15} \mathrm{~N}$} & \multicolumn{2}{|l|}{$\delta^{13} \mathrm{C}$} & \multirow{2}{*}{$\begin{array}{l}\mathrm{N} \\
\mathrm{N}\end{array}$} & \multicolumn{2}{|l|}{$\mathrm{C}: \mathrm{N}$} & \multicolumn{2}{|c|}{$\delta^{13} \mathrm{C}_{\text {lipid-corr }}$} \\
\hline & & & Mean & SE & Mean & SE & & Ratio & SE & Mean & SE \\
\hline \multirow[t]{15}{*}{ Marine } & \multirow[t]{3}{*}{ Texel } & Crangon crangon & 13.2 & 0.4 & -14.9 & 0.6 & 20 & 3.6 & 0.06 & -14.6 & 0.6 \\
\hline & & Pleuronectes platessa & 14.0 & 0.2 & -16.2 & 0.5 & 19 & 3.4 & 0.04 & -16.1 & 0.5 \\
\hline & & Pomatoschistus microps & 15.2 & 0.5 & -14.3 & 0.2 & 2 & 3.6 & 0.08 & -14.0 & 0.3 \\
\hline & \multirow[t]{3}{*}{ Vlieland } & Crangon crangon & 12.2 & 0.2 & -13.2 & 0.2 & 7 & 3.7 & 0.06 & -12.8 & 0.2 \\
\hline & & Pleuronectes platessa & 11.6 & 0.3 & -14.5 & 0.3 & 4 & 3.5 & 0.06 & -14.4 & 0.3 \\
\hline & & Pomatoschistus microps & 14.1 & 0.6 & -15.4 & 0.8 & 3 & 4.0 & 0.06 & 15.1 & 1.3 \\
\hline & \multirow[t]{3}{*}{ Terschelling } & Crangon crangon & 12.9 & 0.2 & -14.4 & 0.1 & 17 & 3.7 & 0.03 & -14.1 & 0.1 \\
\hline & & Pleuronectes platessa & 12.3 & 0.2 & -15.8 & 0.2 & 8 & 3.7 & 0.03 & -15.5 & 0.2 \\
\hline & & Pomatoschistus microps & 14.9 & 0.2 & -15.8 & 0.5 & 7 & 4.1 & 0.08 & -15.0 & 0.5 \\
\hline & \multirow[t]{3}{*}{ Ameland $^{\mathrm{a}}$} & Crangon crangon & 12.8 & 0.2 & -14.6 & 0.3 & 56 & 3.7 & 0.02 & -14.3 & 0.3 \\
\hline & & Pleuronectes platessa & 13.0 & 0.2 & -16.4 & 0.4 & 38 & 3.5 & 0.03 & -16.2 & 0.4 \\
\hline & & Pomatoschistus microps & 14.7 & 0.2 & -15.5 & 0.4 & 12 & 4.0 & 0.07 & -14.8 & 0.3 \\
\hline & \multirow[t]{3}{*}{ Schiermonnikoog } & Crangon crangon & 12.3 & 0.2 & -15.1 & 0.8 & 11 & 3.7 & 0.02 & -14.8 & 0.8 \\
\hline & & Pleuronectes platessa & 11.8 & 0.4 & -19.7 & 1.4 & 5 & 3.7 & 0.06 & -19.3 & 1.4 \\
\hline & & Pomatoschistus microps & 14.7 & 0.2 & -15.5 & 0.4 & 12 & 4.0 & 0.07 & -14.8 & 0.3 \\
\hline \multirow[t]{3}{*}{ Mixture } & \multirow[t]{3}{*}{ All islands } & Total $^{\text {b }}$ & 12.8 & 0.5 & -24.2 & 0.8 & 44 & 4.3 & 0.2 & -23.2 & 0.8 \\
\hline & & Gasterosteus aculeatus (90.8\%) & 12.4 & 0.5 & -24.9 & 0.8 & 40 & 4.4 & 2.2 & -23.8 & 0.9 \\
\hline & & Osmerus eperlanus $(9.2 \%)$ & 16.3 & 0.3 & -17.1 & 0.2 & 4 & 3.2 & 0.02 & -17.2 & 0.3 \\
\hline \multirow[t]{4}{*}{ Freshwater } & \multirow[t]{4}{*}{ All islands } & Total $^{\text {b }}$ & 15.9 & 0.8 & -27.5 & 0.4 & 46 & 3.4 & 0.06 & -27.5 & 0.3 \\
\hline & & Perca fluviatilis (24.1\%) & 18.0 & 0.2 & -26.7 & 0.2 & 7 & 3.2 & 0.01 & -26.9 & 0.2 \\
\hline & & Pungitius pungitius (19.4\%) & 7.8 & 0.4 & -30.2 & 0.5 & 24 & 3.9 & 0.07 & -29.7 & 0.4 \\
\hline & & Rutilus rutilus (56.5\%) & 17.8 & 0.3 & -26.8 & 0.4 & 15 & 3.2 & 0.02 & -26.9 & 0.4 \\
\hline
\end{tabular}

Selected prey species contributed $>2 \%$ of the diet assessed with regurgitate analyses. C isotopes were normalized for the effect of lipid concentration $\left(\delta^{13} C_{\text {lipid-corr }}\right)$, using a correction based on the C:N ratio given by Post et al. (2007)

${ }^{a}$ Because low numbers of main prey species were collected on Ameland, mean values of all islands were used

${ }^{b}$ Dietary ratios of the main prey based on the regurgitate analysis ( $>2 \%$; see Table 2$)$ were used to calculate the mean stable isotope values of Mixture and Freshwater for prey input in SIAR

Table 2 Mean stable isotope values of spoonbill chicks used as an input for diet reconstruction via SIAR

\begin{tabular}{|c|c|c|c|c|c|c|c|c|c|c|c|}
\hline \multirow[t]{2}{*}{ Island } & \multirow[t]{2}{*}{ Tissue } & \multicolumn{2}{|l|}{$\delta^{15} \mathrm{~N}$} & \multicolumn{2}{|l|}{$\delta^{13} \mathrm{C}$} & \multicolumn{2}{|l|}{ TOC } & \multicolumn{2}{|l|}{$\mathrm{TN}$} & \multicolumn{2}{|l|}{$\mathrm{C}: \mathrm{N}$} \\
\hline & & Mean & SE & Mean & SE & Mean & SE & Mean & SE & Mean & SE \\
\hline \multirow[t]{2}{*}{ Texel $(n=48)$} & Cells & 14.82 & 0.14 & -16.31 & 0.23 & 47.86 & 0.19 & 14.96 & 0.07 & 3.20 & 0.01 \\
\hline & Plasma & 16.41 & 0.15 & -16.53 & 0.20 & 42.66 & 0.27 & 9.99 & 0.10 & 4.28 & 0.04 \\
\hline \multirow[t]{2}{*}{ Vlieland $(n=64)$} & Cells & 15.17 & 0.06 & -16.21 & 0.23 & 48.69 & 0.14 & 14.96 & 0.06 & 3.26 & 0.01 \\
\hline & Plasma & 16.59 & 0.14 & -16.91 & 0.30 & 42.03 & 0.26 & 9.86 & 0.09 & 4.27 & 0.03 \\
\hline \multirow[t]{2}{*}{ Terschelling $(n=60)$} & Cells & 15.01 & 0.09 & -19.15 & 0.41 & 48.72 & 0.31 & 15.02 & 0.10 & 3.24 & 0.01 \\
\hline & Plasma & 16.56 & 0.12 & -19.10 & 0.43 & 42.72 & 0.17 & 9.79 & 0.06 & 4.37 & 0.03 \\
\hline \multirow[t]{2}{*}{ Ameland $(n=45)$} & Cells & 15.31 & 0.17 & -19.07 & 0.45 & 49.26 & 0.28 & 15.13 & 0.07 & 3.26 & 0.01 \\
\hline & Plasma & 16.75 & 0.19 & -19.25 & 0.41 & 42.17 & 0.16 & 9.92 & 0.06 & 4.26 & 0.03 \\
\hline \multirow[t]{2}{*}{ Schiermonnikoog $(n=83)$} & Cells & 15.52 & 0.10 & -19.83 & 0.41 & 49.32 & 0.14 & 15.22 & 0.05 & 3.24 & 0.00 \\
\hline & Plasma & 17.21 & 0.10 & -20.37 & 0.43 & 43.33 & 0.20 & 10.10 & 0.05 & 4.29 & 0.02 \\
\hline
\end{tabular}

TN Total nitrogen (\%), TOC Total organic carbon (\%)
Regurgitates $(n=128)$ produced during the catching and ringing sessions (Fig. 1) were collected individually in separate plastic bags. Regurgitates were stored in a freezer $\left(-20^{\circ} \mathrm{C}\right)$ on the same day. Single regurgitates were put on a plate for inspection and, with water added, light-weight items such as shrimp tails, uropods, heads, claws, and 
other whole or almost intact individuals collected first. The remaining light-weight debris was removed by placing the regurgitate in a 800-ml glass beaker filled with water to $600 \mathrm{ml}$ and mixing it with a magnet and magnetic stirrer until all matter was in suspension. To remove the uninformative debris, the mixture in the beaker was carefully overflown by placing the beaker under a slowly running tap. The remaining sample was put on a glass petri dish in order to extract all identifiable parts under a binocular microscope.

The items included otoliths, vertebrae, ventral and dorsal spine, cleithrums, urohyals, bullae, premaxillae, pharyngeal, dentaries, some other bones, insect fragments, crustacean fragments such as heads, carapaces, tails, telsons, uropods, claws (fragments, e.g. dactylus, propodus), legs, swimming pads and skin of amphibian. All parts were classified to the lowest taxonomic level possible, and the size of the parts was used to estimate the length and mass of the individuals (Leopold et al. 2001; C. J. C. et al., unpublished data). Note that, to calculate length and mass from the size of the parts, we used some regression curves developed using larger fish (Leopold et al. 2001), which possibly distorted the estimated length of the small fish. Then, we determined the number of individuals per species, accounting for size and number and orientation of parts per individual.

This study is based on samples collected in the summers of 2012 and 2013. As the sampling of different components (regurgitates, stable isotope values of prey and spoonbills) was not complete in either year, we can not compare the years and present composite values. Unless stated otherwise, the mean and accuracy is given by mean \pm SE. Differences in diet between colonies was statistically analysed with ANOVA using Statistica 10, while graphs were made using Sigmaplot 12.3.

\section{Results}

The analysis of regurgitates demonstrated that nestling spoonbills on the Wadden Sea islands are fed a great variety of prey of marine and freshwater origin (Table 3). Summarising the information in overall mass terms (Fig. 3), the diet of nestling spoonbills consisted for the greater part (59\%) of marine prey from the Wadden Sea. Contrary to expectation, brown shrimp contributed only $12 \%$ to this. The main prey species were flatfish (seemingly predominantly plaice) at $26 \%$, three-spined stickleback (22\%), gobies (17\%). These species had a higher biomass and length, relative to brown shrimp [Pleuronectes platessa, biomass $1.07 \pm 0.04 \mathrm{~g}$, total length $36.1 \pm 0.5 \mathrm{~mm}(n=1124)$; Gasterosteus aculeatus, biomass $1.40 \pm 0.07 \mathrm{~g}$, total length $49.9 \pm 0.5 \mathrm{~mm}(n=637)$; Gobidae, biomass $0.81 \pm 0.04 \mathrm{~g}$, total length $39.9 \pm 0.4 \mathrm{~mm}$
( $n=961)$; C. crangon, biomass $0.19 \pm 0.0041 \mathrm{~g}$, total length (head-tail) $24.3 \pm 0.1 \mathrm{~cm}(n=2391)]$.

Apart from the marine prey, the remaining part of the diet consisted of freshwater prey (29\%, comprising mostly three-spined sticklebacks; Fig. 3) and prey that could have originated from more than one water type (13\%). Figure 4 represents the diet of spoonbill nestlings (regurgitate analysis; Fig. 4a), during the previous few days (isotope analysis based on plasma tissue; Fig. 4b), and that over about a month of nestling life (isotope analysis based on RBC tissue; Fig. 4c) (Rodnan et al. 1957). Restricting the number of sources in SIAR to three (marine, mixture and freshwater) instead of five (Fig. 4b, c), made no meaningful difference to the contributions of marine prey to the diet (mean difference $3.01 \pm 2.63 \%$ ). During the whole nestling period, spoonbill nestlings are mainly fed with marine prey, except for chicks on Texel which mainly had been fed sticklebacks on the day of capture (Fig. 4a) after having been fed a lot of shrimp in the previous weeks (Fig. 4c). Whereas the contribution of flatfish in the diet did not differ between colonies, the contribution of three-spined stickleback decreased from west to east [Fig. 4a, ANOVA ${ }_{\text {Flattish }} ; F_{(4,123)}=0.668, p=0.615$, ANOVA $\left._{\text {Stickleback }} ; F_{(4,123)}=23.34, p<0.001\right]$. The contribution of gobies varied significantly between islands [ANOVA Gobiidae; $F_{(4,123)}=2.51, p=0.045 ;$ Fig. 4 a] although without the data for Texel, the contribution of gobies was uniform (ANOVA $_{\text {Gobiidae without Texel }} ; F_{(3,106)}=0.489, p=0.690$ ). The isotope-based diet reconstructions confirmed that nestling spoonbills were mainly fed marine prey, with fish (mainly gobies and flatfish) and brown shrimp contributing most to the diet (Fig. 4b, c).

\section{Discussion}

As expected, most prey delivered to growing spoonbill chicks on the barrier islands had a marine origin, indicating that they were caught in the Wadden Sea by the provisioning parents. This means that the growth of chicks is 'fuelled' by local prey resources, rather than resources from afar (e.g. found in freshwater habitats on the mainland). Herring gulls Larus argentatus breeding in the same areas have been shown to sometimes provision chicks with freshwater food item collected far away in inland areas (Bukacinska et al. 1996). According to a study by El-Hacen et al. (2014), who reconstructed their diet based on feather isotopes, freshwater prey are the main food source for spoonbill chicks on Schiermonnikoog early in the breeding season, and are replaced by marine items later on, matching the time of the year that this study was carried out. For chicks born in June-July 2010, El-Hacen et al. (2014) found a contribution of brown shrimp of $37 \%$, which is more than the SIAR estimates of 
Table 3 Spoonbill diet on the barrier islands of the Dutch Wadden Sea in 2012-2013, based on regurgitate analyses

\begin{tabular}{|c|c|c|c|c|c|c|c|c|c|c|c|c|c|}
\hline \multicolumn{2}{|c|}{ Year: 2012-2013 } & \multicolumn{2}{|c|}{$\begin{array}{l}\text { Texel } \\
(n=18)\end{array}$} & \multicolumn{2}{|c|}{$\begin{array}{l}\text { Vlieland } \\
(n=60)\end{array}$} & \multicolumn{2}{|c|}{$\begin{array}{l}\text { Terschelling } \\
(n=15)\end{array}$} & \multicolumn{2}{|c|}{$\begin{array}{l}\text { Ameland } \\
(n=2)\end{array}$} & \multicolumn{2}{|c|}{$\begin{array}{l}\text { Schiermon- } \\
\text { nikoog } \\
(n=33)\end{array}$} & \multicolumn{2}{|c|}{$\begin{array}{l}\text { Totals } \\
(n=128)\end{array}$} \\
\hline Habitat & Prey item & Mean & $\mathrm{SE}$ & Mean & SE & Mean & SE & Mean & SE & Mean & $\mathrm{SE}$ & Mean & SE \\
\hline \multirow[t]{20}{*}{ Marine } & Total & 34.2 & 7.5 & 55.8 & 4.3 & 71.7 & 6.9 & 67.7 & 19.3 & 69.9 & 5.3 & 58.5 & 3.0 \\
\hline & Pleuronectes platessa & 20.6 & 7.1 & 24.4 & 3.2 & 33.5 & 6.5 & 25.6 & 1.2 & 28.0 & 3.9 & 25.9 & 2.2 \\
\hline & Gobiidae & 5.8 & 1.5 & 20.6 & 2.6 & 17.7 & 3.3 & 12.9 & 4.5 & 16.2 & 3.1 & 16.9 & 1.6 \\
\hline & Gobiidae & 5.8 & 1.5 & 20.6 & 2.6 & 17.5 & 3.2 & 12.9 & 5.5 & 16.2 & 3.1 & 16.9 & 1.6 \\
\hline & Pomatoschistus minutus & 0.0 & 0.0 & 0.0 & 0.0 & 0.2 & 0.2 & 0.0 & 0.0 & 0.0 & 0.0 & 0.0 & 0.0 \\
\hline & Crangon crangon & 7.1 & 1.2 & 7.9 & 1.1 & 15.5 & 4.5 & 7.1 & 4.0 & 21.9 & 2.1 & 12.3 & 1.1 \\
\hline & Other marine prey & 0.7 & 0.3 & 2.9 & 1.2 & 5.0 & 4.1 & 22.0 & 17.9 & 3.9 & 0.7 & 3.4 & 0.8 \\
\hline & Arnoglossus laterna & 0.0 & 0.0 & 0.1 & 0.1 & 0.0 & 0.0 & 0.0 & 0.0 & 0.0 & 0.0 & 0.0 & 0.0 \\
\hline & Carcinidae & 0.6 & 0.3 & 0.1 & 0.1 & 0.0 & 0.0 & 1.9 & 0.0 & 0.5 & 0.5 & 0.3 & 0.1 \\
\hline & Carcinus maenas & 0.0 & 0.0 & 0.4 & 0.2 & 0.6 & 0.4 & 0.0 & 0.0 & 2.0 & 0.5 & 0.8 & 0.2 \\
\hline & Cerastoderma edule & 0.0 & 0.0 & 0.0 & 0.0 & 0.0 & 0.0 & 0.0 & 0.0 & 0.0 & 0.0 & 0.0 & 0.0 \\
\hline & Hydrobia ulvae & 0.0 & 0.0 & 0.0 & 0.0 & 0.0 & 0.0 & 0.0 & 0.0 & 0.0 & 0.0 & 0.0 & 0.0 \\
\hline & Liocarcinus holsatus & 0.0 & 0.0 & 0.0 & 0.0 & 0.1 & 0.1 & 0.0 & 0.0 & 0.1 & 0.1 & 0.1 & 0.0 \\
\hline & Littorina littorina & 0.0 & 0.0 & 0.1 & 0.0 & 0.0 & 0.0 & 0.0 & 0.0 & 0.0 & 0.0 & 0.1 & 0.0 \\
\hline & Macoma balthica & 0.0 & 0.0 & 0.0 & 0.0 & 0.1 & 0.1 & 0.0 & 0.0 & 0.1 & 0.0 & 0.1 & 0.0 \\
\hline & Myoxocephalus scorpius & 0.0 & 0.0 & 0.1 & 0.1 & 4.1 & 4.1 & 0.0 & 0.0 & 0.0 & 0.0 & 0.5 & 0.5 \\
\hline & Mytilus edulis & 0.0 & 0.0 & 0.0 & 0.0 & 0.0 & 0.0 & 0.0 & 0.0 & 0.1 & 0.0 & 0.0 & 0.0 \\
\hline & Nereis virens & 0.0 & 0.0 & 0.0 & 0.0 & 0.0 & 0.0 & 0.0 & 0.0 & 0.2 & 0.2 & 0.1 & 0.0 \\
\hline & Pholis gunnulus & 0.0 & 0.0 & 1.1 & 1.1 & 0.0 & 0.0 & 0.0 & 0.0 & 0.0 & 0.0 & 0.5 & 0.5 \\
\hline & Sprattus sprattus & 0.1 & 0.1 & 0.8 & 0.4 & 0.0 & 0.0 & 20.1 & 0.0 & 0.9 & 0.3 & 0.9 & 0.4 \\
\hline \multirow[t]{9}{*}{ Mixture $^{\mathrm{a}}$} & Total & 61.5 & 8.1 & 32.4 & 3.7 & 9.6 & 3.6 & 32.3 & 19.3 & 12.6 & 3.6 & 28.7 & 2.7 \\
\hline & Gasterosteus aculeatus & 61.4 & 8.1 & 23.3 & 3.0 & 8.0 & 3.3 & 0.0 & 0.0 & 4.2 & 1.3 & 21.6 & 2.5 \\
\hline & Osmerus eperlanus & 0.0 & 0.0 & 2.9 & 1.3 & 0.0 & 0.0 & 0.0 & 0.0 & 3.3 & 1.6 & 2.2 & 0.7 \\
\hline & Other 'mixture' prey & 0.1 & 0.1 & 6.1 & 2.4 & 1.6 & 1.2 & 32.3 & 19.3 & 5.1 & 2.7 & 4.9 & 1.4 \\
\hline & Anguilla anguilla & 0.0 & 0.0 & 0.0 & 0.0 & 0.0 & 0.0 & 0.0 & 0.0 & 4.6 & 2.7 & 1.2 & 0.7 \\
\hline & Atherina presbyter & 0.0 & 0.0 & 0.2 & 0.1 & 0.0 & 0.0 & 0.0 & 0.0 & 0.4 & 0.4 & 0.2 & 0.1 \\
\hline & Palaemon sp. & 0.1 & 0.1 & 2.4 & 1.6 & 1.6 & 1.2 & 32.3 & 19.3 & 0.0 & 0.0 & 1.8 & 0.9 \\
\hline & Platychtys flesus & 0.0 & 0.0 & 1.6 & 1.6 & 0.0 & 0.0 & 0.0 & 0.0 & 0.0 & 0.0 & 0.7 & 0.7 \\
\hline & Zoarces viviparous & 0.0 & 0.0 & 1.9 & 1.1 & 0.0 & 0.0 & 0.0 & 0.0 & 0.0 & 0.0 & 0.9 & 0.5 \\
\hline \multirow[t]{21}{*}{ Freshwater } & Total & 4.2 & 4.2 & 11.8 & 3.3 & 18.7 & 7.3 & 0.0 & 0.0 & 17.5 & 4.5 & 12.8 & 2.2 \\
\hline & Perca fluviatilis & 0.0 & 0.0 & 1.9 & 0.9 & 0.9 & 0.5 & 0.0 & 0.0 & 6.1 & 2.1 & 2.6 & 0.7 \\
\hline & Pungitius pungitius & 0.0 & 0.0 & 4.4 & 1.9 & 0.5 & 0.5 & 0.0 & 0.0 & 0.0 & 0.0 & 2.1 & 0.9 \\
\hline & Rutilus rutilus & 4.2 & 4.2 & 3.8 & 1.4 & 14.7 & 7.2 & 0.0 & 0.0 & 7.9 & 3.0 & 6.1 & 1.5 \\
\hline & Other freshwater prey & 0.1 & 0.0 & 1.8 & 1.1 & 2.6 & 2.0 & 0.0 & 0.0 & 3.5 & 1.6 & 2.1 & 0.7 \\
\hline & Abramis brama & 0.0 & 0.0 & 0.0 & 0.0 & 0.0 & 0.0 & 0.0 & 0.0 & 0.0 & 0.0 & 0.0 & 0.0 \\
\hline & Acilius sulcatus & 0.0 & 0.0 & 0.0 & 0.0 & 0.0 & 0.0 & 0.0 & 0.0 & 0.0 & 0.0 & 0.0 & 0.0 \\
\hline & Blicca bjoerkna & 0.0 & 0.0 & 0.0 & 0.0 & 0.0 & 0.0 & 0.0 & 0.0 & 0.0 & 0.0 & 0.0 & 0.0 \\
\hline & Callicorixa sp. & 0.0 & 0.0 & 0.0 & 0.0 & 0.0 & 0.0 & 0.0 & 0.0 & 0.0 & 0.0 & 0.0 & 0.0 \\
\hline & Coleoptera & 0.0 & 0.0 & 0.1 & 0.0 & 0.1 & 0.0 & 0.0 & 0.0 & 0.0 & 0.0 & 0.0 & 0.0 \\
\hline & Copepoda & 0.0 & 0.0 & 0.0 & 0.0 & 0.0 & 0.0 & 0.0 & 0.0 & 0.0 & 0.0 & 0.0 & 0.0 \\
\hline & Corixa punctate & 0.0 & 0.0 & 0.0 & 0.0 & 0.0 & 0.0 & 0.0 & 0.0 & 0.0 & 0.0 & 0.0 & 0.0 \\
\hline & Corixa sp. & 0.0 & 0.0 & 0.0 & 0.0 & 0.0 & 0.0 & 0.0 & 0.0 & 0.0 & 0.0 & 0.0 & 0.0 \\
\hline & Dytiscus marginalis & 0.0 & 0.0 & 0.0 & 0.0 & 0.0 & 0.0 & 0.0 & 0.0 & 0.0 & 0.0 & 0.0 & 0.0 \\
\hline & Esox lucius & 0.0 & 0.0 & 0.0 & 0.0 & 0.0 & 0.0 & 0.0 & 0.0 & 0.0 & 0.0 & 0.0 & 0.0 \\
\hline & Gobio gobio & 0.0 & 0.0 & 0.5 & 0.5 & 0.0 & 0.0 & 0.0 & 0.0 & 0.0 & 0.0 & 0.2 & 0.2 \\
\hline & Graphoderus sp. & 0.0 & 0.0 & 0.0 & 0.0 & 0.0 & 0.0 & 0.0 & 0.0 & 0.0 & 0.0 & 0.0 & 0.0 \\
\hline & Gymnocephalus cernuus & 0.0 & 0.0 & 1.1 & 0.9 & 2.5 & 2.0 & 0.0 & 0.0 & 1.9 & 0.7 & 1.3 & 0.5 \\
\hline & Notonecta glauca & 0.0 & 0.0 & 0.0 & 0.0 & 0.0 & 0.0 & 0.0 & 0.0 & 0.0 & 0.0 & 0.0 & 0.0 \\
\hline & Orconectes limosus & 0.0 & 0.0 & 0.0 & 0.0 & 0.0 & 0.0 & 0.0 & 0.0 & 1.6 & 1.1 & 0.4 & 0.3 \\
\hline & Sander lucioperca & 0.0 & 0.0 & 0.0 & 0.0 & 0.0 & 0.0 & 0.0 & 0.0 & 0.0 & 0.0 & 0.0 & 0.0 \\
\hline
\end{tabular}


Table 3 (continued)

Dietary content is expressed as a percentage of the biomass contribution per prey. Prey that occurred at $<2 \%$ in the mean Wadden Sea diet (Totals) were grouped

${ }^{\text {a }}$ Prey that occur in marine, brackish and freshwater habitat types

Fig. 3 Overall composition in terms of biomass of the diet of nestling Eurasian Spoonbills in the Dutch Wadden Sea based on analysis of regurgitates. Prey are divided into three water type classes: marine prey from the Wadden Sea (marine), prey that occur in more than one water type (multiple), and freshwater prey from waters from the islands or the mainland (freshwater)

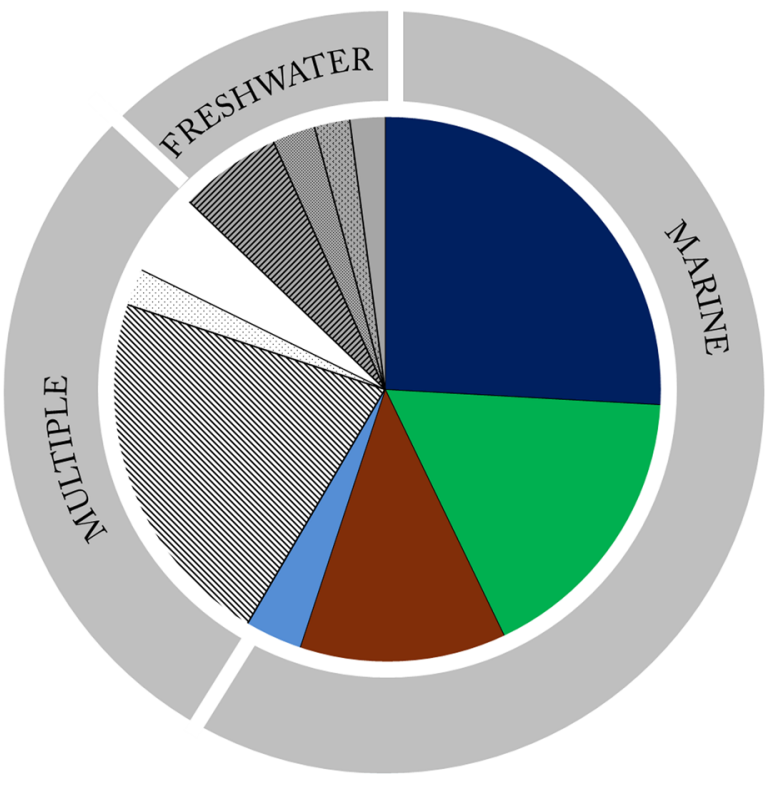

Pleuronectes platessa Gobiidae

Crangon crangon

other Marine prey

Gasterosteus aculeatus

Osmerus eperlanus

$\square$ other Mixture prey

Rutilus rutilus

Perca fluviatilis

Pungitius pungitius

other Freshwater prey
$23 \%$ based on the isotope signature of RBC in the present study (Fig. 4c; Schiermonnikoog).

The finding that flatfish and gobies were the main marine prey species in the Wadden Sea was an unexpected result. After all, the available diet assessments of spoonbills in the Wadden Sea, based on what was taken as common knowledge (Wintermans and Wymenga 1996; Altenburg and Wymenga 1997; Hollander 1997), visual observations of ingested food items (van Wetten and Wintermans 1986a, b), visual examination of the stomach content of a single dead spoonbill (Tinbergen 1933), or direct observations of prey found in feeding areas (Kemper 1986a, b; van Wetten and Wintermans 1986a, b), all indicate that brown shrimp should be the main prey. Indeed, the colour and structure of regurgitates beguilingly suggest brown shrimp to be the main component; this is due to the low digestibility of the shrimps' chitin exoskeletons (Jackson et al. 1992) compared with the fish meat which is more rapidly digested by the spoonbills.

Our analysis rectifies the notion that shrimp is the main marine prey (at least for the chicks), and suggests that small fish rather than brown shrimp contribute most to the spoonbill nestling diets. Our finding is consistent with prey-preference experiments with a captive second-year spoonbill reported in the grey literature by van Wetten and Wintermans (1986a). When simultaneously offered fish and shrimp, spoonbill preferred fish (van Wetten and Wintermans 1986a). This may be explained by their higher digestibility (Jackson et al. 1992), higher biomass per prey item, and possibly smaller handling times (van Gils et al. 2005). Also, unlike marine fish, shrimp are isotonic with sea water (Spaargaren 1971), yielding a salt load that spoonbills may try to avoid (Gutiérrez 2014; Gutiérrez and Piersma 2016).

From the late 1980s onwards, the Wadden Sea lost a substantial part of its important function as a nursery for flatfish (van der Veer et al. 2011), with small populations of the young age classes of plaice lingering on. Long-term trends in the western Wadden Sea intertidal area are consistent with this view, with a decrease of juvenile flatfish abundance, but without clear trends for gobies and brown shrimp (Jung et al., in review). Furthermore the stocks of adult shrimp in the deeper parts of the Wadden Sea first generally increased (Tulp et al. 2012), followed by a decrease again due to overfishing (Tulp et al. 2016). In view of their preference to provision their chicks with fish rather than shrimp, we suggest that their preferred prey (flatfish) being scarce in recent years will have been the most important factor leading to density-dependent recruitment declines of growing spoonbill colonies and the rapid saturation of colony sizes in the Wadden Sea (Oudman et al. 2017). During the initial phase of their population recovery [1965-1990 (Lok et al. 2013)], spoonbills might actually have benefited from the favourable food conditions in the form of an abundance of 

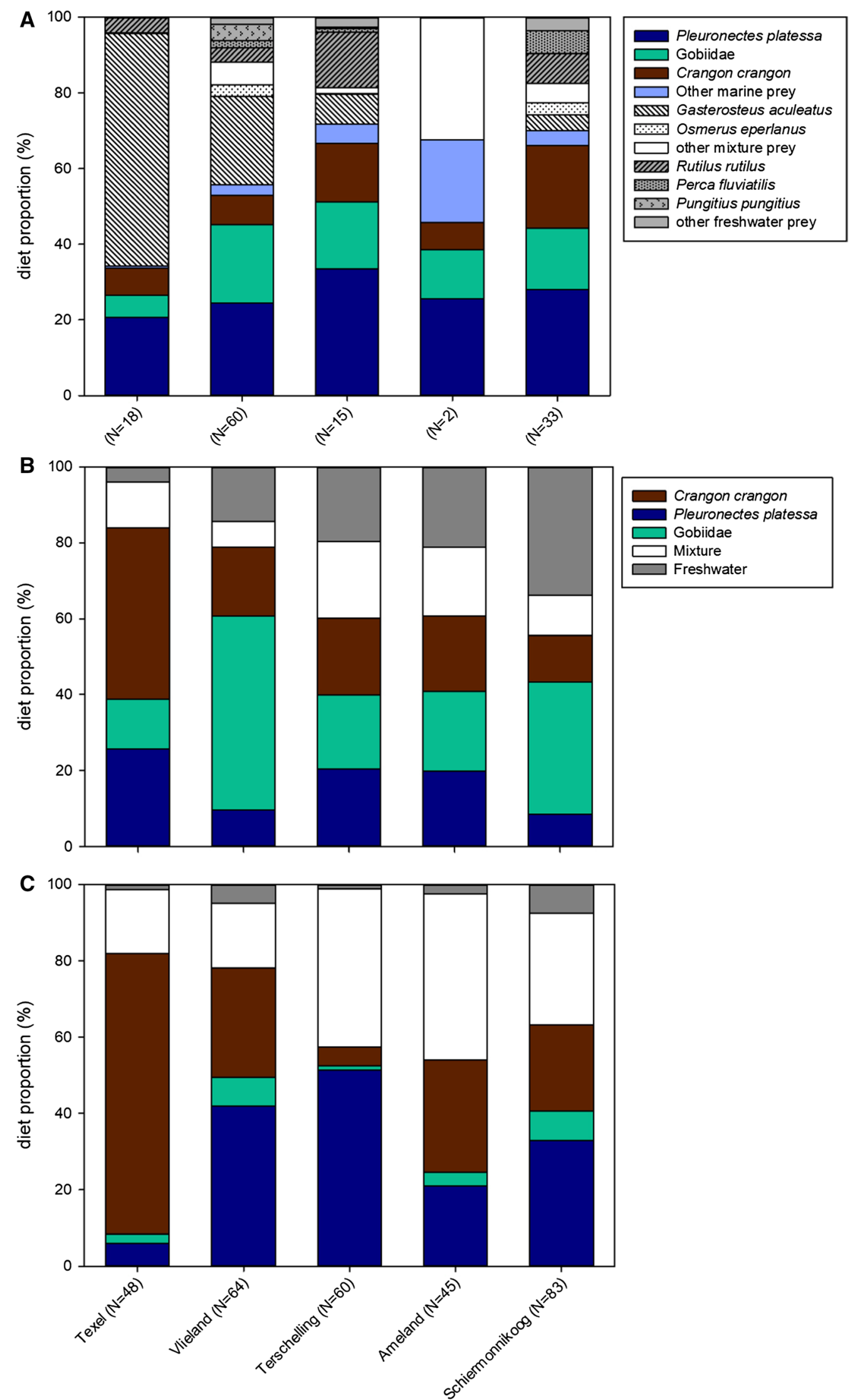

Fig. 4 Diet of nestling spoonbills on the different Wadden Sea islands based on a regurgitate analysis, $\mathbf{b}$ stable isotope analysis of plasma, and $\mathbf{c}$ stable isotope analysis of red blood cells 
juvenile flatfish and gobies rather than mature brown shrimp (van der Veer et al. 2011), compared to relatively greater densities of brown shrimp recently.

The current levelling off of the growth of the spoonbill population breeding on the Wadden Sea barrier islands (Oudman et al. 2017) is associated with low stocks of their favourite small fish prey (van der Veer et al. 2011). A preference for small fish rather than shrimp would make colony growth characteristics good indicators of the abundance of small fish in the Wadden Sea. This is a state of affairs that appears comparable to that of the harbour seals (Phoca vitulina) in the Dutch Wadden Sea, where population levelling off is also explained by limited access to (larger) fish (Brasseur et al. 2018). We predict that successful (fishery) management towards recovery of the former densities of young flatfish, or an increase of small and juvenile fish abundance in general, will be tracked by changing spoonbill diets (more fish), improved breeding success, and an increase in the size of spoonbill colonies across the Wadden Sea.

Acknowledgements This study would not have been possible without the participation of Eric Menkveld, Carl Zuhorn, Arjan Zonderland, Oene de Jong, Richard Kiewiet, the late Frits Oud, and Erik Jansen (nature managers on the Wadden Islands; It Fryske Gea, Natuurmonumenten and Staatsbosbeheer) and all spoonbill volunteers, especially Harry Horn and Roos Kentie. We thank Rebecca Reurslag for her help with the regurgitate analyses; Stefan Schouten, Thomas Leerink and Kevin Donkers (NIOZ) for technical assistance with the stable isotope analyses; and Sarina Jung for the population trends of Gobiidae. We are grateful to Stefan Schouten for giving us advanced isotopic advice. The fieldwork was carried out under Dutch welfare (DEC) protocol RuG-4752 amendement D. This study was carried out as part of the Waddensleutels (WF203930) and Metawad (WF209925) projects, both supported by the Waddenfonds.

Open Access This article is distributed under the terms of the Creative Commons Attribution 4.0 International License (http://creativeco mmons.org/licenses/by/4.0/), which permits unrestricted use, distribution, and reproduction in any medium, provided you give appropriate credit to the original author(s) and the source, provide a link to the Creative Commons license, and indicate if changes were made.

\section{References}

Altenburg W, Wymenga E (1997) Voedsel voor lepelaars. Birdlife Netherlands, Zeist, p 32

Boere GC, Piersma T (2012) Flyway protection and the predicament of our migrant birds: a critical look at international conservation policies and the Dutch Wadden Sea. Ocean Coast Manage 68:157-168

Brasseur SMJM, Reijnders PJH, Cremer J, Meesters E, Kirkwood R, Jensen LF, Je $\beta$ A, Galatius A, Teilmann J, Aarts G (2018) Echoes from the past: regional variations in recovery within a harbour seal population. PLoS One 13:e0189674

Bukacinska M, Bukacinski D, Spaans AL (1996) Attendance and diet in relation to breeding success in Herring Gulls (Larus argentatus). Auk 113:300-309
Caut S, Angulo E, Courchamp F (2009) Variation in discrimination factors $\left(\delta^{15} \mathrm{~N}\right.$ and $\left.\delta^{13} \mathrm{C}\right)$ : the effect of diet isotopic values and applications for diet reconstruction. J Appl Ecol 46:443-453

Cherel Y, Hobson KA, Hassani S (2005) Isotopic discrimination between food and blood and feathers of captive penguins: implications for dietary studies in the wild. Physiol Biochem Zool 78:106-115

de Goeij P, Kemper JH, van Wetten JCJ (1985) De lepelaar in het waddengebied. Waddenbulletin 20:5-7

de Goeij P, Overdijk O, Lok T, Piersma T (2015) La fortuna cambiante de las espatulas de la via de la vuelo del atlantico oeste. In: Hortas F, Ruiz J (ed) La migracion intercontinental de la espatula (Platalea leucorodia). Desarrollo Pesquero Cadiz-Estrecho and Sociedad Gatidana de Historia Natural, Cadiz, pp 99-109

de Jonge VN, Essink K, Boddeke R (1993) The Dutch Wadden Sea: a changed ecosystem. In: Best EPH, Bakker JP (eds) Netherlandswetlands: proceedings of a symposium held in Arnhem, the Netherlands, December 1989. Springer, Dordrecht, pp 45-71

Dietz MW, Spaans B, Dekinga A, Klaassen M, Korthals H, van Leeuwen C, Piersma T (2010) Do Red Knots (Calidris canutus islandica) routinely skip Iceland during southward migration? Condor 112:48-55

El-Hacen E-HM, Piersma T, Jouta J, Overdijk O, Lok T (2014) Seasonal variation in the diet of spoonbill chicks in the Wadden Sea: a stable isotopes approach. J Ornithol 155:611-619

Eriksson BK, van der Heide T, van de Koppel J, Piersma T, van der Veer HW, Olff H (2010) Major changes in the ecology of the Wadden Sea: human impacts, ecosystem engineering and sediment dynamics. Ecosystems 13:752-764

Gutiérrez JS (2014) Living in environments with contrasting salinities: a review of physological and behavioural responses in waterbirds. Ardeola 61:233-256

Gutiérrez JS, Piersma T (2016) Ecological context determines the choice between prey of different salinities. Behav Ecol 2:530-537

Hahn S, Hoye BJ, Korthals H, Klaassen M (2012) From food to offspring down: tissue-specific discrimination and turn-over of stable isotopes in herbivorous waterbirds and other avian foraging guilds. PLoS One 7:e30242

Hancock JA, Kushlan JA, Kahl MP (2010) Storks, ibises and spoonbills of the world. Black, London

Hobson KA, Welch HE (1992) Determination of trophic relationships within a high arctic marine food web using $\delta^{13} \mathrm{C}$ and $\delta^{15} \mathrm{~N}$ analysis. Mar Ecol Prog Ser 84:9-18

Hollander H (1997) Themanummer: lepelaars, 3-gangen menu. Vogelnieuws, Birdlife Netherlands, Zeist 16

Jackson S, Place AR, Seiderer LJ (1992) Chitin digestion and assimilation by seabirds. Auk 109:758-770

Jung AS, Dekker R, Germain M, Philippart CJM, Witte JIJ, van der Veer HW (2017) Long-term shifts inintertidal predator and prey communities in the Wadden Sea and consequences for food requirements andsupply. Mar Ecol Prog Ser 579:37-53. https:// doi.org/10.3354/meps 12263

Kemper JH (1986a) Foraging strategy in the spoonbill, Platalea leucordia. Report 33. Instituut voor Taxonomische Zoölogie, Amsterdam

Kemper JH (1986b) Voedselbeperking voor de lepelaar van het zwanenwater. Lev Nat 87:66-71

Leopold MF, van Damme CJG, Phillipart CJM, Winter CJN (2001) Otoliths of North Sea fish: fish identification key by means of otoliths and other hard parts. Expert-Center for Taxonomic Identification, Amsterdam

Lok T, Overdijk O, Horn H, Piersma T (2009) The spoonbill Platalea leucorodia population of the Wadden Sea islands: does population growth level off? Limosa 82:149-157 
Lok T, Overdijk O, Tinbergen JM, Piersma T (2013) Seasonal variation in density dependence in age-specific survival of a long-distance migrant. Ecology 94:2358-2369

Lok T, Overdijk O, Piersma T (2014) Interpreting variation in growth of Eurasian Spoonbill chicks: disentangling the effects of age, sex and environment. Ardea 102:181-194

Lok T, Veldhoen L, Overdijk O, Tinbergen JM, Piersma T (2017) An age-dependent fitness cost of migration? Old trans-Saharan wintering spoonbills breed later than birds from Europe and late breeders have lower recruitment. J Anim Ecol 86:998-1009

Oudman T, de Goeij P, Piersma T, Lok T (2017) Colony-breeding eurasian spoonbills in the Netherlands: local limits to population growth with expansion into new areas. Ardea 105(2):113-124. https://doi.org/10.5253/arde.v105i2.a2

Parnell AC, Inger R, Bearhop S, Jackson AL (2010) Source partitioning using stable isotopes: coping with too much variation. PLoS One 5:e9672

Phillips DL, Inger R, Bearhop S, Jackson AL, Moore JW, Parnell AC, Semmens BX, Ward EJ (2014) Best practices for use of stable isotope mixing models in food-web studies. Can J Zool 92:823-835

Polis GA, Hurd SD (1995) Extraordinarily high spider densities on islands: flow of energy form the marine to terrestrial food webs and the absence of predation. Proc Natl Acad Sci USA 92:4382-4386

Post DM (2002) Using stable isotopes to estimate trophic position: models, methods, and assumptions. Ecology 83:703-718

Post DM, Layman CA, Arrington DA, Takimoto G, Quattrochi J, Montana CG (2007) Getting to the fat of the matter: models, methods and assumptions for dealing with lipids in stable isotope analyses. Oecologia 152:179-189

Reise K, Baptist M, Burbridge P, Dankers N, Fischer L, Flemming B, Oost AP, Smit CJ (2010). The Wadden Sea: a universally outstanding tidal wetland. Common Wadden Sea Secretariat (CWSS), Wilhelmshaven, Germany

Rodnan GP, Ebaugh FG, Fox MRS, Chambers DM (1957) The life span of the red blood cell and the red blood cell volume in the chicken, pigeon and duck as estimated by the use of $\mathrm{Na}_{2} \mathrm{Cr}^{51} \mathrm{O}_{4}$. with observations on red cell turnover rate in the mammal. Bird Reptile 12:355-366

Spaargaren DH (1971) Aspects of the osmoregulation in the shrimps Crangon crangon and Crangon allmanni. Neth J Sea Res $3: 275-335$

Swennen (1976) Wadden Seas are rare, hostitable and productive. In: Smart M (ed) Proceedings of the International Conference on the
Conservation of Wetlands and Waterfowl, Heiligenhafen. International Waterfowl Research Bureau, Slimbridge, pp 184-198

Tinbergen L (1933) Lepelaarmaag. Lev Nat 38:262

Tulp I, Bolle LJ, Meesters E, de Vries P (2012) Brown shrimp abundance in northwest European coastal waters from 1970 to 2010 and potential causes for contrasting trends. Mar Ecol Prog Ser 458:141-154

Tulp I, Chen C, Haslob H, Schulte K, Siegel V, Steenbergen J, Temming A, Hufnagl M (2016) Annual brown shrimp (Crangon crangon) biomass production in northwestern Europe contrasted to annual landings. ICES J Mar Sci 73:2539-2551. https://doi. org/10.1093/icesjms/fsw141

van de Kam J, Ens BJ, Piersma T, Zwarts L (2004) Shorebirds: an illustrated behavioural ecology. KNNV, Utrecht

van der Hut RMG (1992) Biologie en de bescherming van de lepelaar Platalea leucorodia. Vogelbescherming, Zeist

van der Veer HW, Koot J, Aarts G, Dekker R, Diderich W, Freitas V, Witte JIJ (2011) Long-term trends in juvenile flatfish indicate a dramatic reduction in nursery function of the Balgzand intertidal, Dutch Wadden Sea. Mar Ecol Prog Ser 434:143-154

van Gils JA, de Rooij SR, van Belle J, van der Meer J, Dekinga A, Piersma T, Drent R (2005) Digestive bottleneck affects foraging decisions in Red Knots Calidris canutus. I. Prey choice. J Anim Ecol 74:105-119

van Roomen M, Laursen $\mathrm{K}$, van Turnhout $\mathrm{C}$, van Winden E, Blew J, Eskildsen K, Günther K, Hälterlein B, Kleefstra R, Potel P, Schrader S, Luerssen G, Ens BJ (2012) Signals from the Wadden sea: population declines dominate among waterbirds depending on intertidal mudflats. Ocean Coast Manage 68:79-88

van Wetten JCJ, Wintermans GJM (1986a) The food ecology of the spoonbill, Platalea leucorodia. Internal report. Instituut voor Taxonomische Zoölogie, Universiteit Amsterdam

van Wetten JCJ, Wintermans GJM (1986b) Voedselecologie van de lepelaars van het Zwanenwater en Texel. Graspieper 6:96-109

Wintermans GJM, Wymenga E (1996) Voedsel voor lepelaars; knelpunten, oplossingsrichtingen en aanbevelingen voor de inrichting en het beheer van voedselgebieden van Lepelaars. Altenburg \& Wymenga Ecological Research and Consultancy

Wolff WJ (2005) The exploitation of living resources in the Dutch Wadden Sea: a historical overview. Helgol Mar Res 59:31-38

\section{Affiliations}

\section{Jeltje Jouta ${ }^{1,2} \oplus \cdot$ Petra de Goeij ${ }^{1,2,3} \cdot$ Tamar Lok $^{2,4} \cdot$ Estefania Velilla $^{2,5} \cdot$ Cornelis J. Camphuysen $^{2} \cdot$ Mardik Leopold $^{6}$. Henk W. van der Veer ${ }^{2} \cdot$ Han Olff $^{1} \cdot$ Otto Overdijk $^{3} \cdot$ Theunis Piersma $^{1,2}$}

Jeltje Jouta

Jeltje.Jouta@NIOZ.nl

1 Conservation Ecology Group, Groningen Institute for Evolutionary Life Sciences (GELIFES), University of Groningen, P.O. Box 11103, 9700 CC Groningen, The Netherlands

2 Department of Coastal Systems, NIOZ Royal Netherlands Institute for Sea Research and Utrecht University, P.O. Box 59, 1790 AB Den Burg, Texel, The Netherlands
3 Werkgroep Lepelaar, Visserspad 10, 9142 VN Moddergat, The Netherlands

4 Biostatistics and Population Biology, Centre d'Ecologie Fonctionnelle et Evolutive, UMR 5175, Montpellier, France

5 Department of Ecological Science, Faculty of Earth and Life Sciences, VU University Amsterdam, De Boelelaan 1085, 1081 HV Amsterdam, The Netherlands

6 Present Address: Ecosystems, Wageningen IMARES, P.O. Box 57, 1780 AB Den Helder, The Netherlands 